\title{
MECHANISM OF GOALS SETTING FOR THE SUBSIDIARIES OF ECONOMIC CONGLOMERATES
}

\author{
Denys Mykhailyk \\ candidate of economic sciences, associate professor \\ Department of International Economic Relations \\ Zaporizhzhya Institute of Economics and Information Technologies \\ 69041, Zaporizhia, Kiyashka str., 16B \\ E-mail:D.Mikhaylik@econom.zp.ua \\ Phone number: 050-590-74-71 \\ ORCID: https:/ / orcid.org/0000-0003-2425-0437
}

\begin{abstract}
This study solves the problem of translating global corporate goals and values to the all levels of the corporate hierarchy, which is relevant for economic conglomerates, integrated enterprises and other multilevel business entities. The subject of research is the methods of effective formation of the goals of economic systems with a multilevel organizational structure. The goal of this study is to synthesize an effective mechanism for forming the goals by subsidiaries of economic conglomerates, which ensures the effectiveness of goal-setting at all levels of organizational and economic structure. This study is based on some specific and general scientific methods, such a conception of goal-driven management and the principles of S.M.A.R.T, which have been expanded and supplemented to ensure the coherence of goals at different levels of the corporate organizational structure. The study also uses elements of the methodology of reflexive management and the principles of a Systems theory and Systems analysis. To achieve this goal, the article proposes an extended goal structure, which is presented through a combination of parameters that specify the result, resources, time, priority rank, the relationship with the goals and values of higher levels. Companies and their subsystems within the corporate structure, it is proposed to consider as homogeneous elements of the goal-setting system. These assumptions allowed us to develop a universal mechanism for goal setting using the principles of reflexive management. It allows us to take into account: input goals, goals of one-tier structures, available resources, intention and exogenous pressure on the decision-maker. The results of the study can be used to improve the goal-setting system of business entities with a multilevel organizational structure, as well as their associations. Conclusions: the implementation of mechanisms for the goals setting as a part of decision support system will increase the efficiency of business entities, as well as the effectiveness of whole its management system.
\end{abstract}

Keywords: conglomerate, integrated business entities, goal, goal setting, goal structure, reflexive management

Постановка проблеми у загальному вигляді.

Незважаючи на те, що теорією і практикою менеджменту давно визнана необхідність розглядати цілепокладання в якості одного 3 найважливіших компонентів системи управміння підприємствами та їх об'єднаннями, існуючі методи цілепокладання переважно пропонуються в описовому вигляді і розраховані на формування відповідних навичок у топ менеджерів. Це обмежує зону ефективного цілепокладання вищими ешелонами керування. У той же час аналіз роботи вітчизняних підприємств показує, що ефективність цілепокладання швидко знижується в процесі сходження за рівнями організаційної структури [1]. Тобто для отримання ефективної віддачі, система організації цілепокладання повинна охопцювати всі рівні ієрархії управління.

Тож, предметом дослідження $є$ методи ефективного формування цілей економічних систем із багаторівневою організаційною структурою.
Оскільки економічні конгломерати за своєю сутністю мають найбільшу кількість рівнів організаційної структури серед можливих форм об'єднань підприємств, пробцема ефективної організації цімепокладання набуває дия них особливу актуальність.

Враховуючи великі витрати на організацію ефективної системи цілепокладання існуючими методами, завдання щодо створення такої системи може бути вирішено тільки за умов автоматизації процесів, пов'язаних 3 управлінням цілепокладанням. Дия цього в свою чергу необхідно вирішити завдання формалізації механізмів формування цілей в підсистемах економічного конгломерату.

Аналіз останніх досліджень та публікаиій

За визначенням Ю. Робул, функція цілепокладання $\epsilon$ сполучною манкою, яка з'єднує, 3 одного боку, макрорівень, представлений системою вищого ступеня охопцення, а 3 іншого - мікрорівень, на рівні окремої фірми. Разом із тим правильне цілепокладання забезпечує зв'язок між 
виробництвом, інноваціями, маркетинговою політикою та фінансовою результативністю [1]. А.С. Зєніна-Біліченко визначає, що переорієнтація діяльності кожного структурного підроздіку на досягнення цілей i конкретизація результатів їх діяльності по забезпеченню останніх $є$ одним 3 найважливіших завдань реалізації i розвитку функцій цілепокладання на підприємствах [2].

Аналіз досліджень закордонних вчених показує, що дана проблема також вважається ними актуальною, та розглядається для багатьох видів соціально-економічних систем. Так, в роботі [3] розглядаються інструменти підвищення ефективності цілепокладання в умовах реалізації проектів електронного уряду. Автори роботи [4] пропонують методи вдосконалення процесів цілепокладання в корпораціях та економічних конгломератах, які засновані на інтеграції процесів цілепокладання до інтегрованих корпоративних систем. Автори наголошують на необхідності забезпечення досягнення загальної мети, зберігаючи при цьому місцеві цілі для кожного проекту. Разом із тим авторами підкреслюється нестача відомостей про теоретичні взаємозв'язки, які передбачають роботу над досягненням цілей у функціональних сферах одночасно із загальною метою дия тієї самої системи [4].

Таким чином метою даного дослідження $\epsilon$ синтез ефективного механізму формування цілей підприємств у складі економічних конгломератів, який забезпечує збереження ефективності цілепокладання на всіх рівнях організаційно-економічної структури.

Викладення основного матеріалу

Розглянемо підходи до визначення поняття "ціль". Різні джерела по-різному трактують це поняття залежно від описуваної предметної області. Так, у психології "ціль" визначається, як "напрямок орієнтації поведінки" [5, с. 711], як «Психосоціальна якість, що випливає 3 почуття ініціативи, завдяки яким у дитини поступово зростає здатність до цілеспрямованої поведінки" [6, с. 563], як "спрямованість мислення і поведінки мюдини на досягнення об'єкта його бажань, фантазій" [7, с. 112].

У соиіальних науках ціль - це бажаний результат; щось, чого мюдина прагне досягти

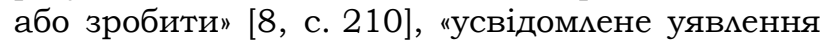
про той результат, який повинен бути досягнутий шляхом спрямованих зусиль особистості в ході її взаємодії і спілкування." [9, c. 402], "усвідомлений образ передбаченого результату, на досягнення якого спрямована дія мюдини" [10, с. 591].

У військовій справі цілмю називають об'єкт застосування будь-якої зброї, який повинен бути в результаті зруйновано або пошкоджено.

В технічних дисциплінах (в широкому розумінні цього слова, що охоплює предметні області, де результат може бути виражений в чисельному вираженні) ціллю зазвичай $\epsilon$ поліпшення стану будь-яких показників. Однак, можуть висуватися цілі стабілізації, обмеження або підтримання показників в екстремальному стані. [11].

Аналіз представцених визначень дає можливість визначити ціль, як бажаний стан певного набору показників, досягнення якого обмежена часом та іншими ресурсами. Отже, базову структуру цілі складають показники що задають:

- результат;

- pecypcu;

- uac.

у цілому, запропонована структура відповідає концепції "управління за цілями" та розробленим в її рамках принципом S.M.A.R.T., згідно з яким мета повинна бути:

Specific- конкретна, визначена.

Measurable - вимірна.

Achievable - досяжна.

Relevant - відповідна контексту.

Timed/Time-bounded - прив'язана до точки/інтервалу у часі.

Виконання принципів S.M.A.R.T. в даний час вважається обов'язковим дия будь-якої ефективної системи цілепокмадання [12, 13].

Ряд сучасних вчених пропонує доповнити принципи S.M.A.R.T. властивостями зв'язності, щоб забезпечити можливість побудови дерева цілей організації [14]. Крім того в умовах децентралізації управління виникають ситуації з постановкою одному підроздіку суперечливих цілей, або таких цілей, що явно перевищують його можливості. У цьому випадку необхідно забезпечувати урахування пріоритетів різних цімей

Таким чином, базова структура цікі може бути розширена за рахунок додаткових параметрів:

По-перше, дия кожної ціні може бути заданий певний ранг прiopumemy.

По-друге, в структуру можуть бути вкцючені параметри, що описують пї зв'язок з цілями i цінностями більш високих рівнів. Це дозволить давати не тільки відповідь на питання "що зробити?", але й на питання "навіщо?".

Таким чином, розширена структура иілі являє собою комбінацію параметрів, що задають:

- результат;

- ресурси;

- час;

- ранг прiоритету;

- зв'язок з иілями і иінностями вищих рівнів.

На практиці при формулюванні цілі керівником додаткові параметри можуть бути пропущені, або задані нечітко. У цьому випадку керований підрозділ має самостійно відновити відсутню інформацію у відповідності зі своїми уявменнями. Від точності відновцення замежить 
точність організації подальшого процесу цілепокладання.

Відповідно до принципів системного підходу, система цілепокладання економічної системи складається з ряду підсистем, які на поточному рівні абстракції можна розглядати як однорідні.
Підсистемами системи цілепокладання $\epsilon$ керівники всіх рівнів ієрархії, які в мітературі по управлінню системами традиційно називаються особами, що приймають рішення (ОПР). Модемь інформаційних потоків ОПР і відповідної підсистеми можна представити наступним чином (рис. 1).

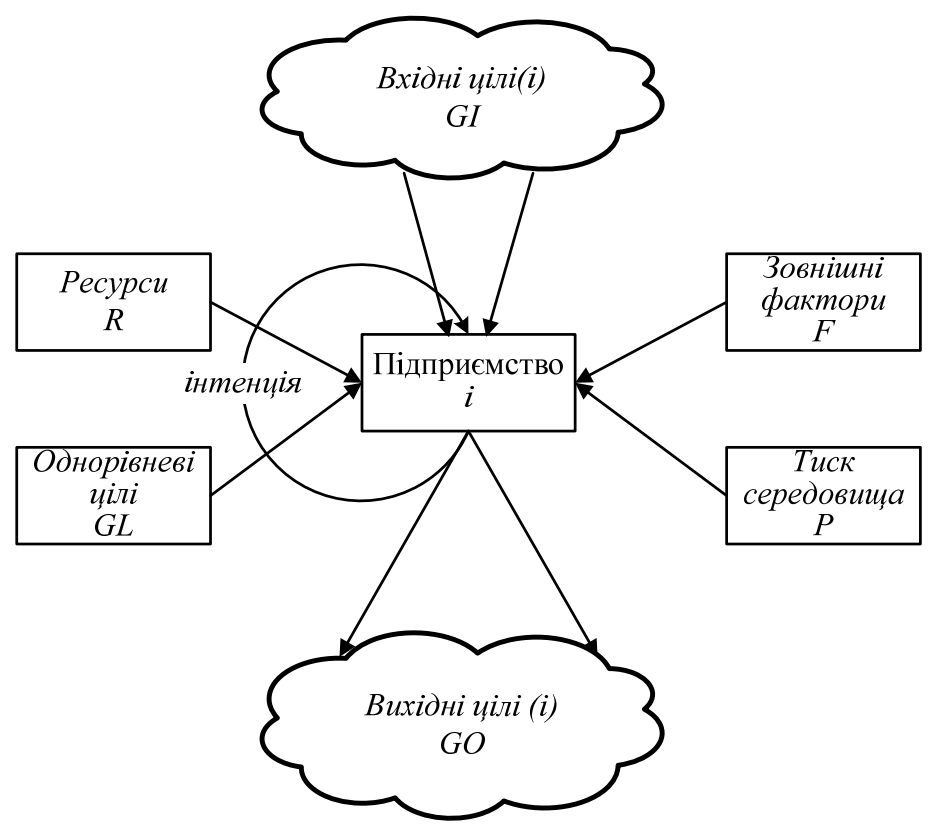

Рис. 1. Системи цілепокладання дия структурного елементу економічного конгломерату.

Вхідними потоками підсистеми (i) є цілі, отримані від верхнього рівня керівництва (GI), що виключає її застосування дия вищого керівництва конгломерату, яке здійснює генерування стратегічних цімей.

Вихідні інформаиійні потоки (вихідні цілі) GO - це цілі, призначені для нижчестоящих рівнів управціння, а також однорівневим структурам. Саме адекватне формування цих цімей $\epsilon$ сутністю цілепокладальної діяльності ОПР. Можна виділити три основних різновиди вихідних цілей $\mathrm{GO}$

1. цікі, досягнення яких безпосередньо необхідно дия досягнення цілей $G I$.

2. цілі, досягнення яких необхідно дия забезпечення нормального функціонування підроздіку $i$.

3. інші цілі підроздіку $i$.

Крім вхідної інформації, на фрормування вихідних цілей впливають також:

Цілі однорівневих підсистем GL. У мінійній ієрархічній системі однорівневі підсистеми не мають налагодженого горизонтальної взаємодії.

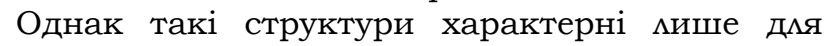
невеликих підприємств, де ОПР має можливість тримати під контролем весь процес виконання рішень. На великих підприємствах та об'єднаннях підприємств діють структури управління $з$ розвинутими горизонтальними зв'язками. Так, мінійно-функціональна структура передбачає цілепокцадання як по вертикалі (Аінійні керівники), так і по горизонталі (функціональні керівники).

Слід зазначити, що в межах одного рівня управління вихідні цілі одних елементів структури можуть бути вхідними однорівневими цілями інших. Через потенційно велику кількість цілей однорівневих підсистем, на практиці завжди діє механізм, що дозволяє підроздіку фікьтрувати те, що безпосередньо пов'язано з його діяльністю. При цьому від ефективності даного механізму багато в чому залежить ефективність цілепокладання в цілому. При необхідності виділяти цілі, одержувані від однорівневих елементів, і цілі, що транслюються іншим однорівневим елементам, будемо позначати відповідно $\mathrm{GL}^{\text {in }}(i)$ i GL ${ }^{\text {out }}(i)$

Ресурси, наявні в розпорядженні ОПР позначимо через R. Сукупність ресурсів, всіх типів, що $€$ в розпорядженні ОПР, або підконтрольних йому. Очевидно, що ресурси, які може використовувати ОПР, можна визначити, як частину загальних ресурсів підприємства. При цьому в більшості випадків для досягнення окремої цілі потрібно менше ресурсів, ніж $€$ у підприємства, ресурси, потрібні дия досягнення всієї сукупності цілей перевищують загальні ресурси підприємства. Таким чином, необхідність обліку інформації про ресурси обумовмена тим, що однією 3 причин виникнення конфмікту цілей $є$ брак 
ресурсів для виконання всіх вхідних завдань, внаслідок чого ОПР вимушено перерозподіляє ресурси у відповідності зі своїми уявценнями про пріоритетність цімей.

Фактори зовнішнього середовища $F$. Сукупність зовнішніх, по відношенню до підприємства $i$, факторів, які впливають на виконання цілей. Очевидно, що множина таких факторів входить до сукупності факторів, що впливають на роботу економічної структури вищого рівня.

Тиск зовнішнього середовиша $P$. Інформаційний потік, який можна інтерпретувати як ступінь примусу 3 боку зовнішнього середовища до прийняття ОПР того, чи іншого рішення. Тобто термін "зовнішній" слід розглядати по відношенню до ОПР, а не по відношенню до підприємства.

Слід акцентувати увагу на істотному розходженні між факторами зовнішнього середовища і тиском зовнішнього середовища. Перші є об'єктивними проявами економічного і правового поля, в якому працює підприємство. На відміну від них тиск зовнішнього середовища сприймається ОПР суб'єктивно, тобто ступінь його сприйняття, і відповідна реакція ОПР багато в чому визначаються його особистими якостями - вихованням, соціальним статусом і т. п. При цьому, виходячи 3 даного вище уточнення до поняття "зовнішнього середовища", джерела тиску можуть перебувати не мише за межами підприємства, але i всередині його.

Iнтениія IN - схильність ОПР до вибору певного рішення, або певного характеру дій. $Є$

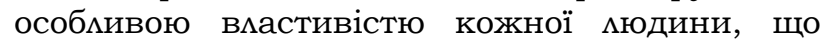
розвивається на підставі його темпераменту, виховання, життєвого досвіду, інтелекту та інших вроджених або набутих якостей.

Дія останніх двох потоків - тиску зовнішнього середовища та інтенції - на поведінку суб'єкта і прийняття їм рішень обгрунтовані в рамках теорії рефцексивного управління. Обидва фактори є суб'єктивними, тобто їх вплив буде індивідуальним для кожного ОПР. По суті, саме вони визначають те, що в одних i тих же умовах та при наявності однакової інформації різні керівники можуть приймати різні рішення. Як інтенція ОПР, так і його реакція на тиск зовнішнього середовища не можуть бути фрормалізовані і враховані. Тим не менш, в деяких межах можна впливати на ці інформаційні потоки.

3 урахуванням вищевикладеного, можна зробити висновок, що сукупність вихідних цілей системи є результатом аналізу і обробки вхідних потоків інформації, 3 урахуванням тиску зовнішнього середовища та інтенції ОПР:

$$
\mathrm{GI}(i), \mathrm{GL}(i), R(i), F(i), P(i), \mathrm{IN}(i) \Rightarrow \mathrm{GO}(i)
$$

Схематично модемь формування цілей для підприємства, або групи підприємств у складі економічного конгломерату, можна уявити як сукупність п'яти основних механізмів:

- фільтрації цілей;

- аналітики;

- формалізації цілей;

- аналізу ресурсів;

- вибору цілей.

Зв'язки цих механізмів один 3 одним, а також 3 вхідними та вихідними інформаційними потоками показано на рис. 2.

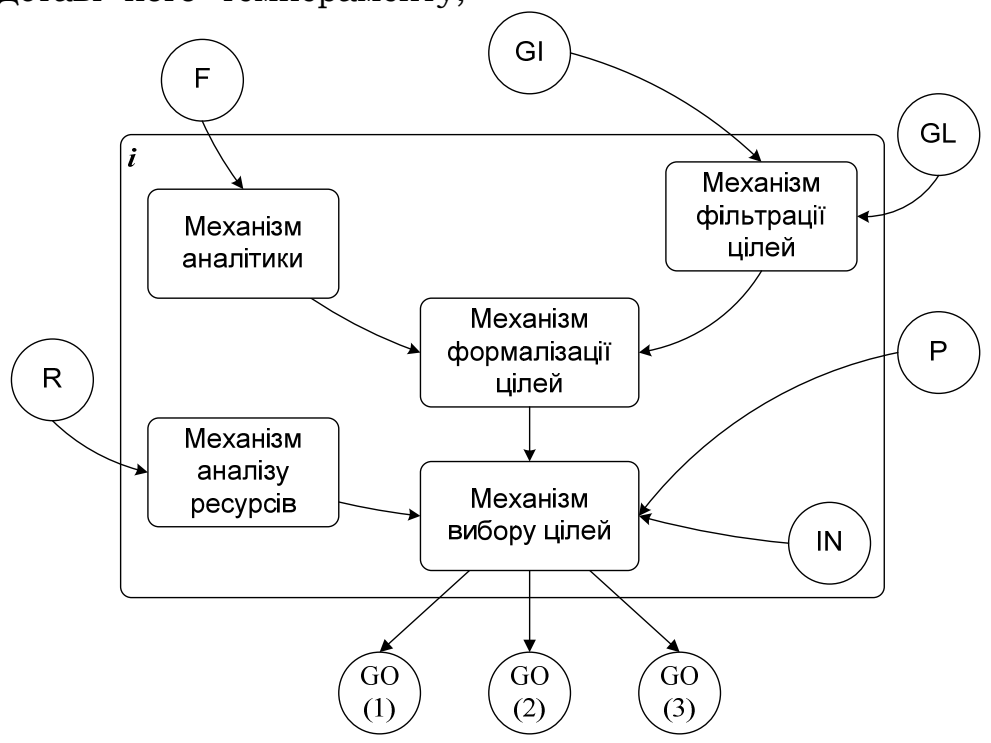

Рис. 2. Механізм формування цілей підприємством у складі економічного конгломерату.

Залежно від розміру і складу підприємства, механізми, які показані на рис. 2, можуть бути як окремими структурними одиницями (наприклад, в складі департаменту стратегічного реалізовуватися підприємств.

$\begin{array}{ccr}\text { планування), } & \text { так } & \text { i } \\ \text { особисто } & \text { керівниками }\end{array}$


Механізм формалізаиї иілей служить дмя формування списку всіх можливих цілей підроздіку - свого роду "програми максимум". При цьому враховується тільки потенційний ефект від досягнення цікей, без прив'язки до наявних у наявності ресурсів. Вхідною інформацією $є$ результати аналізу факторів зовнішнього середовища, а також вищих цілей і однорівневих підрозділів.

Механізм аналітики включає засоби аналізу зовнішніх факторів та їх впливу на процес ціледосягання. У процесі аналізу виявляється перелік найбільш значущих зовнішніх факторів, ступінь i механізми їх впливу на роботу підприємства, складається перспективний прогноз їх зміни.

Механізм фрільтраиї̈ відсікає цілі із низькою значимістю від подальшого розгляду. Фактично тут відбувається подім цілей на "важливі" i "неважливі". Необхідність цього механізму зумовлена тим, що ресурси, необхідні підприємствам у складі конгломерату для досягнення всіх цілей (включаючи горизонтальні цілі), як правимо, значно перевищують наявні ресурси. Крім того, серед безлічі вхідних цілей можуть зустрічатися такі, що суперечать одна іншій. Тому вже на стадії підготовки до формалізації доцільно виключити свідомо "зайві" цілі.

В рамках механізму аналізу ресурсів проводиться формалізації матеріальних, тимчасових $\mathrm{i}$ трудових ресурсів, що $\epsilon$ у наявності, а також визначаються можливі резерви і межі використання. Результатом роботи цього механізму повинна бути добре структурована довідкова інформація за всіма видами ресурсів підприємства.

Механізм вибору ијлей вирішує завдання формування підсумкової комбінації вихідних цілей підроздіку, виходячи зі сформованого раніше набору можливих цілей i наявних ресурсів. Рішення даної задачі є пріоритетною ром^ю ОПР у процесі цілепокладання та іiі формалізація в даний час не може бути виконана ефективно. У той же час ефективність діяльності ОПР може бути підвищена шляхом створення i використання в роботі автоматизованої системи підтримки прийняття рішень, що полегшує доступ до довідкової інформації та аналіз ефективності прийнятих рішень.

\section{МЕХАНІЗМ ФОРМУВАННЯ ЦІАЕЙ ПІДПРИЕМСТВ У СКААДІ ЕКОНОМІЧНИХ КОНГАОМЕРАТІВ}

Михайцик д.П., к.е.н., доцент, Кафедра Міжнародних економічних відносин, Запорізький інститут економіки та інформаційних технологій, 69041, м. Запоріжжя, вул. Кияшка, 16Б, Е-таil: D.Mikhaylik@econom.zp.ua, Контактний тем.: 050-590-74-71, ORCID: https://orcid.org/0000-0003-24250437

Дане дослідження вирішує проблему трансляції глобальних корпоративних цілей і цінностей на всі рівні організаційної ієрархії, яка є актуальною для економічних конгломератів, інтегрованих підприємств та багатьох інших суб'єктів економічної діяльності. Предметом дослідження є методи ефективного формування цілей економічних систем із багаторівневою організаційною структурою. Метою даного
Як вже було згадано вище, більшість перерахованих механізмів в існуючих структурах управління реалізуються самим ОПР. Виняток становлять механізми аналізу ресурсів та аналітики зовнішніх факторів. У той же час сучасні інтелектуальні технології

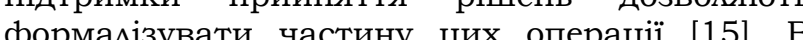
цьому контексті слід звернути увагу на то, що ефективність діяльності ОПР значною мірою залежить від ефективності роботи механізму фільтрації. В існуючих системах управління цація цілей практично цікком покладена участь в роботі механізму інтенції зовнішнього середовища. Однак, судячи з того, що "вміння розставцяти пріоритети" цінується як одне 3 найбільш важливих якостей дівника, здібності до цього $є$ мише у diлас. Tому формахізація механізму завдань з формування системи цімепокладання підприємств у складі економічних конгломератів. Рішення цієї задачі може бути отримано через реалізацію системи управління .

вкАючений в систему уприі цілепокладанням, $є$ механізм формалізації цілей. Його реалізація передбачає автоматизацію процесів ув'язування цілей 3 наявними ресурсами та іншими обмеженнями, тобто забезпечення виконання умови "досяжності" з комплексу принципів S.M.A.R.T.

Висновки.

Запропонований механізм дозволяє забезпечити формування цілей та збереження ефективності цілепокладання на всіх рівнях підприємств у складі економічних конгломератів. Реалізація механізмів формування цілей підсистем у складі системи підтримки прийняття рішень підвищить ефективність діяльності економічних суб'єктів, також ефективність системи управління в окремих механізмів і доведення іх до стадіі практичної реалізації. 
дослідження є синтез ефективного механізму формування цілей підприємств у складі економічних конгломератів, який забезпечує збереження ефективності цілепокладання на всіх рівнях організаційноекономічної структури. Методологічною основою дослідження є концепція "управління за цілями" та принципах S.M.A.R.T, які розширено та доповнено з метою забезпечення зв'язності цілей на різних рівнях корпоративної організаційної структури. В дослідженні також використовуються елементи методомогії рефцексивного управління та принципи системного підходу та системного аналізу. Дия досягнення поставценої мети в статті запропоновано розширену структуру цілі, яку представцено через комбінацію параметрів, що задають результат, ресурси, час, ранг пріоритету, зв'язок з цілями і цінностями вищих рівнів. Підприємства та їх підсистеми у рамках корпоративної структури, запропоновано розглядати як однорідні елементи системи цілепокладання. Ці припущення дозволили розробити універсальний механізм формування цілей із використанням принципів рефлексивного управління. Такий механізм враховує вхідні цілі, цілі однорівневих структур, інтенцію та тиск на особу, що приймає рішення, наявні ресурси. Резумьтати дослідження можуть бути використані для вдосконалення системи цілепокладання підприємств та організацій із складною організаційною структурою, а також їх об'єднань. Висновок: Реалізація механізмів формування цілей підсистем у складі системи підтримки прийняття рішень підвищить ефективність діяльності економічних суб’єктів, а також ефективність системи управління в цікому.

К^ючові слова: конгломерат, інтегроване підприємство, ціль, цілепокладання, структура цілі, рефмексивне управ іння.

\section{Мiтература}

1. Робум Ю. Динаміка розвитку маркетингових систем, розвиток інновацій і завдання маркетингової політики. Підприємниитво та інновації. 2019. № 9. С. 43-48. https://doi.org/10.37320/2415-3583/9.6

2. Зєніна-Біліченко А. С. Реалізація функції цілепокладання і розвитку підприємств в системі управління. Ефрективна економіка. 2010. № 9. http://nbuv.gov.ua/UJRN/efek_2010_9_16

3. Sarantis D., Charalabidis Y., Askounis D. A goal-driven management framework for electronic government transformation projects implementation. Government Information Quarterly. 2011. Vol. 28 (1). P. 117-128. https://doi.org/10.1016/j.giq.2009.10.006.

4. Chang J., Jiang J., Klein G., Wang E. Enterprise system programs: Goal setting and cooperation in the integration team. Information \& Management. 2019. Vol. 56(6). $P . \quad 103-137$. https://doi.org/10.1016/j.im.2018.12.005.

5. Жмуров В.А. Большая энциклопедия по психиатрии. 2-е изд. Элиста: Джангар, 2012. 864 с.

6. Хьем А., Зигмер Д. Гмоссарий к «Теории мичности». 3-е изд. СПб.: Питер, 2009. 608 с.

7. Аейбин В. Словарь-справочник по психоанализу. М.:АСТ, 2010. 145 с.

8. Чалдини Р., Кенрик Д., Нейберг С. Социальная психология: глоссарий к книге. СПб.: ПраймЕврознак, 2002. 256 с.

9. Кондратьев М. Ю., Ильин В. А. Азбука социального психолога-практика. М.: ПЕР СЭ, 2007. 464 с.

10.Анцупов А.Я., Шипилов А.И. Словарь конфмиктолога. 3-е изд М.: ЭКСМО, 2010. 656 с.

11.Цель. Матеріали Вільної енциклопедії. URL: http://ru.wikipedia.org/wiki/Цель (дата звернення: 15.08.2020).

12.Боссиди $\Lambda$. Чаран Р. Исполнение. Система достижения целей. М.: Альпина Паблишер, 2012.328 с.

13.Andersen E. S., Grude K. V., Haug T. Goal directed project management: effective techniques and strategies. 4th ed. London: Kogan Page Publishers, 2009. 272 p.

14.Середа Г. Досвід університетів в області впровадження КPI-показників досягнення стратегічних цімей. Економіка і організація управління. 2018. №. 4 (32). С. 86-99. https://doi.org/10.31558/23072318.2018.4.9

15.Аисенко Ю.Г., Мінц О.Ю. Моделювання інноваційних інтелектуальних систем прийняття рішень в економіці. Нейро-нечіткі технологї моделювання в економіиі. 2017 . № 6. С. 90-141. https://doi.org/10.33111/nfmte.2017.090

\section{References}

1. Robul Y. (2019) Dynamics of development of marketing systems, development of innovations and tasks of marketing policy. (Dynamika rozvytku marketynhovykh system rozvytok innovatsii $i$ zavdannia marketynhovoi polityky.) Pidpryiemnytstvo ta innovatsii, 9, 43-48. https://doi.org/10.37320/2415-3583/9.6

2. Zienina-Bilichenko A. S. (2010) Implementation of the function of goal setting and development of enterprises in the management system (Realizatsiia funktsii tsilepokladannia i rozvytku pidpryiemstv v systemi upravlinnia). Efektyvna ekonomika, http://nbuv.gov.ua/UJRN/efek_2010_9_16

3. Sarantis D., Charalabidis Y., Askounis D. (2011) A goal-driven management framework for electronic government transformation projects implementation. Government information quarterly, 28 (1), $117-128$. https://doi.org/10.1016/j.giq.2009.10.006.

4. Chang J., Jiang J., Klein G., Wang E. (2019) Enterprise system programs: Goal setting and cooperation in the integration team. Information \& Management, $103-137$. https://doi.org/10.1016/j.im.2018.12.005.

5. Zhmurov V.A. (2012) Great encyclopedia of psychiatry (Bol'shaya entsiklopediya po psikhiatrii). (2nd ed.). Elista: Dzhangar. 
6. Hjelle L., Ziegler D. (2009) Glossary to Personality Theories. (3rd ed.). SPb: Piter

7. Leibyn V. (2010) Dictionary of psychoanalysis (Slovar-spravochnik po psihoanalizu). Moscow: AST

8. Kenrick, D. T., Neuberg, S. L., \& Cialdini, R. B. (2010). Social psychology: Goals in interaction (5th ed.). Boston, MA: Allyn \& Bacon.

9. Kondratev M. Yu. Ylyn V. A. (2007) Alphabet of social psychologist-practitioner (Azbuka socialnogo psihologa-praktika). Moscow: PER SE.

10.Ancupov A.Ya., Shipilov A.I. (2010) Dictionary of conflictology (Slovar konfliktologa). (3rd ed.) Moscow: EKSMO.

11.Goal (n.d). in Wikipedia. http://ru.wikipedia.org/wiki/Цемь.

12.Bossidy, L.; Charan, R. (2002). Execution: The Discipline of Getting Things Done. Moscow: Albina Publisher.

13.Andersen E. S., Grude K. V., Haug T. (2009) Goal directed project management: effective techniques and strategies (4th ed.) London: Kogan Page Publishers

14.Sereda H. (2018) Experience of universities in the field of implementation of KPI-indicators to achieve strategic goals. (Dosvid universytetiv $v$ oblasti vprovadzhennia kpi-pokaznykiv dosiahnennia stratehichnykh tsilei). Ekonomika i orhanizatsiia upravlinnia, 4 (32), 86-99. https://doi.org/10.31558/2307-2318.2018.4.9

15.Lysenko Yu.H. Mints O.Yu. (2017) Modeling of innovative intelligent decision-making systems in economics (Modeliuvannia innovatsiinykh intelektualnykh system pryiniattia rishen $v$ ekonomitsi). Neuro-fuzzy modeling technologies in economy, 6, 90-141. https://doi.org/10.33111/nfmte.2017.090 